Industrial Health, 1976, 14, 45.

\title{
COMPARISON OF CADMIUM PRETREATMENT AND PHENOBARBITAL TREATMENT FOR THE MITIGATION OF ACUTE CADMIUM TOXICITY
}

The biological response to cadmium toxicity is mitigated with the conditioned body as pretreatment with small dose of cadmium $^{1)}$ and phenobarbital treatment ${ }^{2}$. And the animal recieved by cadmium pretreatment ${ }^{3)}$ and phenobarbital treatment ${ }^{2)}$ was accelerated the ability of cadmium accumulation in liver. However, the accelaeration of cadmium intake in liver on animal pretreated with small dose of cadmium mainly due to the induction of metallothionein ${ }^{4}$ and that on animal treated with phenobarbital will due to other mechanism than induction of metallothionein. ${ }^{5)}$ Accordingly the mechanism of cadmium intake in liver or of tolerance to cadmium toxicity differs between both treated animal. So the author reported in this study to the comparison of effect of cadmium pretreatment and phenobarbital treatment for the mitigation on acute cadmium toxicity by the method of mortality curve to the cadmium doses.

Male ICR mice weighing 30 to $35 \mathrm{~g}$ were used in this experiment. Cadmium pretreated mice were given intraperitoneally $0.6 \mathrm{mg} \mathrm{Cd} / \mathrm{kg}$, and phenobarbital treated mice were given subcutaneously $30 \mathrm{mg} / \mathrm{kg}$ of phenobarbital daily for 5 days. At $24 \mathrm{hr}$ after treatment all mice were injected intraperitoneally various doses of cadmium as challenging in each group of 10 mice. The number of dead mice was counted for 7 days after challenging of cadmium.

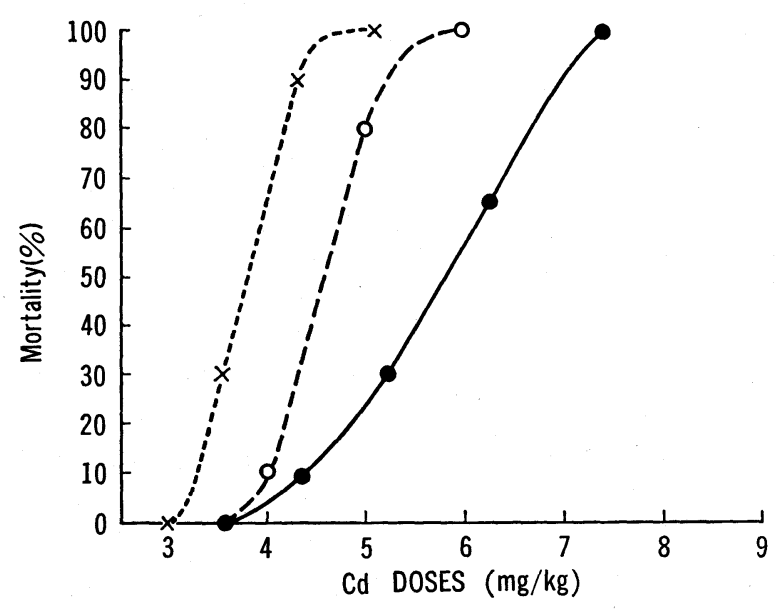

$\times---\times \quad$ Non-treatment,

$\bigcirc-\bigcirc$ Subcutaneous injection of $30 \mathrm{mg} / \mathrm{kg}$ of phenobarbital daily for 5 days as treatment,

Intraperitoneal injection of $0.6 \mathrm{mg} \mathrm{Cd} / \mathrm{kg}$ as pretreatment.

Fig. 1. Mortality curves to cadmium on mice treated with phenobarbital and small doses of cadmium. 


\section{H. YOSHIKAWA}

Mortality curves obtained from this experiment are shown in Fig. 1. As shown in this Figure, the mortality curves moved at right side in order of non-treated mice, phenobarbital-treated mice, and cadmium-pretreated mice. This result shows these treatment reduced the acute cadmium toxicity and the cadmium pretreated mice acquired the tolerance to acute cadmium toxicity more than the phenobarbital treated mice.

$50 \%$ lethal doses of these 3 groups were as follow:

$$
\mathrm{LD}_{50} \text { values }
$$

non-treated mice

$$
3.8 \mathrm{mg} \mathrm{Cd} / \mathrm{kg}
$$

phenobarbital treated mice

$$
4.7 \mathrm{mg} \mathrm{Cd} / \mathrm{kg}
$$

cadmium pretreated mice

$$
5.8 \mathrm{mg} \mathrm{Cd} / \mathrm{kg}
$$

As the mechanism of the mitigation to acute cadmium toxicity is still not clear in both groups of the cadmium-pretreatment and the phenobarbital-treatment, this difference of $\mathrm{LD}_{50}$ values could not explain.

The mortality curve make from the phenobarbital treatment shows the sigmoidal curve and is parallel to that from the non-treatment, but the mortality curve make from the cadmium pretreatment gentles compared with the former 2 curves. This fact shows that the tolerance produced by cadmium pretreatment is larger a difference by individuals than that by phenobarbital treatment.

\section{REFERENCES}

1) Yoshikawa, H. (1970). Ind. Health, 8, 184.

2) Yoshikawa, H. and Ohsawa, M. (1975). Toxicol. Appl. Pharmacol., 34, 517.

3) Yoshikawa, H. (1973). Ind. Health, 11, 113.

4) Suzuki, Y. and Yoshikawa, H. (1974). Ind. Health, 12, 141.

5) Yoshikawa, H. and Suzuki, Y. unpublished.

National Institute of Industrial Healsh

Hiroshi YOSHIKAWA

Nagao 6-chome, Tama-ku

Kawasaki, 213 Japan

(Received May 17, 1976) 